\title{
DIGITALISASI ARSIP FOTO UNIVERSITAS DIPONEGORO SEBAGAI LANDASAN IMPLEMENTASI KEBIJAKAN KETERBUKAAN INFORMASI PUBLIK
}

\author{
Oleh: \\ Tri Handayani*, Amin Taufiq Kurniawan** \\ *Program Studi Kearsipan Fakultas Ilmu Budaya Undip \\ **Program Studi Ilmu Perpustakaan Fakultas Ilmu Budaya Undip \\ Jl. Prof. Soedarto, SH Tembalang Semarang 50275 \\ E-mail:tri.handayani.undip@gmail.com \\ amintaufiq@yahoo.com
}

\begin{abstract}
This paper focuses on digitalization archival photo Diponegoro University, as the basis for Diponegoro University towards the era of public information openness. This basis can be realized among others bythe publication digital photo archives of the three traditional missions of academic institutions (tridharma perguruan tinggi) and digital photo archive of administrative activity of Head of the University of Diponegoro through the website of Khazanah Arsip Foto Undip (Collection of Undip Photo Archive). As a conclusion, Khazanah Arsip Foto Undip were digitalized and uploaded to the Undip website were information to the public about the achievements of the University of Diponegoro in organizing the three traditional missions of academic institutions activities, and the information to the public about the achievements of the Head of Diponegoro University policy.
\end{abstract}

Keywords: photo archives digitalization, public information openness, Universitas Diponegoro.

\section{PENDAHULUAN}

Foto merupakan hasil dari kegiatan perekaman suatu obyek maupun peristiwa secara visual (Bowo Herdiyanto, 2001). Keberadaan foto dapat menembus ruang dan waktu, membuka ingatan seseorang terhadap suatu peristiwa yang telah terjadi di masa yang telah lampau. Dengan demikian foto merupakan alat bukti sekaligus sebagai bagian dari sumber informasi. Disebutkan dalam Pasal 1 butir 2 Undang-Undang Nomor 43 Tahun 2009, bahwa “arsip adalah rekaman kegiatan atau peristiwa dalam berbagai bentuk dan media sesuai dengan perkembangan teknologi informasi dan komunikasi yang dibuat dan, pemerintahan daerah, lembaga pendidikan, perusahaan, organisasi politik, organisasi kemasyarakatan, dan perseorangan dalam pelaksanaan kehidupan bermasyarakat, berbangsa, dan bernegara”. Berdasar pada pasal tersebut, diketahui bahwa foto adalah bagian dari arsip.

Universitas Diponegoro merupa-kan perguruan tinggi negeri, dalamhal ini merupakan lembaga pendidikan tinggi publik. Sesuai dengan amanah Pasal 1 butir 9 Undang-Undang Nomor 12 Tahun 2012 tentang Pendidikan Tinggi, maka Universitas Diponegoro menyelenggarakan tridharma perguruan tinggi, yaitu pendidikan, penelitian, dan pengabdian kepada masyarakat. Dinamika atmosfer akademis perguruan tinggi tidak lepas dari peran kebijakan pimpinan perguruan tinggi 
dalam penyelenggaraan pendidikan tinggi. Seluruh kegiatan tridharma perguruan tinggi serta proses penerbitan hingga pelaksanaan kebijakan pimpinan perguruan tinggi direkam dalam berbagai media arsip.

Dengan demikian, sejarah perjalanan kehidupan Universitas Diponegoro dari hulu hingga hilir dapat dilihat di dalam arsip yang dihasilkan sebagai efek samping dari penyelenggaraan administrasi perguruan tinggi. Berdasar pada uraian tersebut dan merujuk pada bagian menimbang UndangUndang Nomor 43 Tahun 2009 tentang Kearsipan, maka diketahui bahwa arsip merupakan identitas sekaligus jatidiri Universitas Diponegoro. Jatidiri Universitas Diponegorop adalah segala sesuatu yang khas dan hanya dimiliki oleh Universitas Diponegoro.

Jatidiri Universitas Diponegoro tampak dalam Pola Ilmiah Pokok (PIP) Universitas Diponegoro, yaitu pengelolaan wilayah tropis dan pantai berwawasan lingkungan ini mempunyai kesempatan positioning terhadap penanganan permasalahan dan pengelolaan wilayah tropis dan pesisir.

Zainuri (http://berita.suaramerdeka.com/ smcetak/gerbang-menuju-universitas-riset/) menyatakan, bahwa "Pemahaman tema Poros Maritim dapat diterjemahkan bahwa kompetensi keilmuan yang dikembangkan terkait dengan pengembangan fisik wilayah pesisir dan pantai, bangunan lepas pantai, fungsi transportasi laut, pemetaan wilayah laut perbatasan, serta eksploitasi dan eksplorasi sumber daya alam. Kewenangan itu menjadi satu nilai tambah dan peningkatan daya saing terhadap pengembangan SDM. ”Artinya adalah Pola Ilmiah Pokok menjadi ruh dari setiap kebijakan akademik Universitas Diponegoro. Kekhasan akademik tersebut terekam di dalam media arsip yang diciptakan di lingkungan Universitas Diponegoro.

Arsip merupakan memori kolektif bagi Universitas Diponegoro, karena rekaman perjalanan penyelenggaraan pendidikan tinggi yang diselenggarakan di setiap periode kepemimpinan rektor, merupakan jalinan bukti kegiatan penyelenggaraan pendidikan tinggi dari masa ke masa. Penyelenggaraan pendidikan tinggi di lingkungan Universitas Diponegoro adalah sejarah bagi Universitas Diponegoro, bukan universitas yang lain. Rekaman sejarah penyelenggaraan pendidikan tinggi Universitas Diponegoro, menjadi acuan para penyelenggaran pendidikan Universitas Diponegoro dalam mempertimbangkan kebijakan yang akan ditempuh untuk penyelenggaraan pendidikan tinggi di masa berikutnya. Isi informasi yang terekam di dalam arsip tersebut, sekaligus menjadi bahan pertanggungjawaban kepada publik tentang penyelenggaraan pendidikan tinggi yang telah dilakukan pada masa yang telah berjalan di masa sebelumnya. Dengan demikian, arsip khususnya dalam kerangka penyimpan memori kolektif perguruan tinggi memiliki nilai informasional dan kebuktian yang tinggi tentang penyelenggaraan pendidikan tinggi sehingga harus dikelola dan diselamatkan oleh negara.

Foto yang menjadi khazanah arsip foto di Laboratorium Program Studi Diploma III Kearsipan Fakultas Ilmu Budaya Undip berupa negatif film dan positif foto yang diakuisisi dari UPT Humas.Fokus penelitian ini adalah digitalisasi arsip foto untuk diupload ke website Undip lengkap dengan deskripsi dari masing-masing foto.Tujuannya adalah untuk memudahkan temubalik foto memori kolektif Universitas Diponegoro. Sebagai memori kolektif dan sumber penelitian, maka pengguna khazanah arsip foto Undip dengan berbagai kepentingan perlu dibantu agar mudah dalam proses temu balik. Maka, pilihan basis web merupakan pilihan tepat agar publik dapat mengetahui penyelenggaraan pendidikan tinggi di Universitas Diponegoro dari masa ke masa tanpa harus berkunjung secara langsung ke laboratorium Program Studi Diploma III Kearsipan Fakultas Ilmu 
Budaya Universitas Diponegoro.Dengan demikian, keberadaan website Khazanah Arsip Foto Undip merupakan langkah Undip menuju era Keterbukaan Informasi Publik.

Penelitian tentang penginventarisasian arsip foto Undip, pengalih-mediaan arsip foto Undip hingga pembuatan aplikasi program temu balik arsip foto berbasis web telah dilakukan pada tahun 2014. Maka, penelitian ini merupakan penelitian terapan mengenai upaya melakukan penyempurnaan terhadap penataan khazanah arsip foto Undip hasil alih media. Sehubungan dengan khazanah arsip foto Undip akan diunggah ke website, maka dilakukan perencanaan pembuatan desain website. Langkah selanjutnya adalah melakukan upload file/website ke hosting. Melalui tahapan tersebut, maka khazanah arsip foto Undip menjadi terorganisasi secara sistematis dan temu baliknya menjadi lebih mudah dan cepat. Oleh karena itu, studi ini akan mengangkat pertama, bagaimana langkah penyempurnaan penataan khazanah arsip foto Undip hasil alih media. Kedua, Bagaimanakah Desain Website Khazanah Arsip Foto Undip yang ideal. Ketiga, apakah hubungan antara digitalisasi arsip foto Universitas Diponegoro dengan implementasi kebijakan keterbukaan informasi publik?

Digitalisasi Arsip Foto Universitas Diponegoro sebagai Landasan Implementasi Kebijakan Keterbukaan Informasi Publik ini merupakan sebuah penelitian deskriptif analitis dengan dukungan data kualitatif. Penelitian ini menggunakan sumber primer berupa arsip foto. Sumber primer selain berupa arsip foto juga berasal dari hasil wawancara para pegawai Universitas Diponegoro yang telah lama mengabdi di Universitas serta para pegawai yang telah purna tugas untuk menanyakan informasi tentang apa? siapa? mengapa? kapan? dimana? bagaimana? yang ada di masingmasing foto.

Selain itu wawancara juga dilakukan kepada pengelola UPT Pusat Komputer tentang jaringan website Universitas Diponegoro serta prosedur untuk melakukan upload website Khazanah Arsip Foto Undip. Wawancara kepada developer, Arsiparis dan staf IT Badan Arsip dan Perpustakaan Provinsi jawa Tengah terkait digitalisasi, pembangunan program website, fitur apa saja yang perlu untuk ditampilkan dalam website arsip foto, desain website khazanah arsip foto yang menarik, edukatif dan informatif. Wawancara ini penting untuk dilakukan agar tidak terjadi salah prosedur dalam penyiapan file yang akan di-upload ke hosting. Metode penelitian yang lain adalah observasi.

Dari observasi ini terlihat secara faktual arsip foto digital yang akan diupload, sistem penataan, worksheet deskripsi arsip foto digital. Observasi atau pengamatan terhadap khazanah arsip foto yang sudah dialih media, sistem penataan yang digunakan, peluang perolehan arsip foto dimasa yang akan datang, bertujuan untuk memperoleh deskripsi yang lebih utuh tentang khazanah arsip foto Undip, nilai informasi yang dapat disajikan kepada para pengguna, sistem temu balik yang tepat untuk digunakan, serta bahasa pemrograman yang tepat untuk digunakna. Gambaran tentang arsip foto digital, gambaran penataan, penanganan, pembuatan desain website serta upload file atau website ke hosting memperkaya pengetahuan dan pemahaman tentang arsip elektronik dan keterbukaan informasi publik.

Selain sumber primer, penelitian ini juga mengacu pada sumber sekunder, yaitu melakukan pencarian data maupun hasil penelitian sebelumnya berupa studi pustaka. Studi ini digunakan sebagai pembanding dalam menjelaskan fenomena-fenomena yang sama: Fenomena yang sama dalam penelitian ini adalah tentang arsip foto hasil alih media (digital), pemanfaatan Microsoft Excel sebagai media pencatat deskripsi arsip foto hasil alih media, nilai informasi yang diperlukan oleh pengguna, kemudahan yang diperlukan para pengguna untuk mengakses 
arsip foto hasil alihmedia serta deskripsi tentang arsip tersebut, aspek hukum arsip foto hasil alih media yang dipublikasikan dengan memanfaatkan website, serta bahasa pemrograman yang paling banyak digunakan oleh para developer untuk pembuatan membuat halaman web.

Penajaman pengumpulan data dan informasi dapat dilakukan dengan menggunakan Focus Group Discussion (FGD).Pada kegiatan ini masing-masing individu secara berkelompok menajam-kan lagi hasil penelitian sebelumnya, khususnya tentang rumusan klasifikasi arsip foto. Penajaman ini perlu dilakukan karena klasifikasi adalah dasar bagi pelaksanaan pengelompokan arsip foto sebelum diinput ke dalam worksheet sebagai sarana temu balik secara elektronik serta dasar dalam penataan arsip foto sehingga sinkron kronologis antara foto dengan deskripsinya. Setelah deskripsi integral tentang struktur sistem penataan arsip foto digital dan bahasa pemrograman telah ditetapkan, maka dilakukan input data ke dalam website secara offline. Setelah website Khazanah Arsip Foto Undip di-upload ke hosting dan siap disajikan kepada publik, maka dilakukan kegiatan workshop tentang keberadaan website ini kepada seluruh unit kerja yang ada di lingkungan Universitas Diponegoro. Tujuannya adalah agar keberadaan website ini diketahui oleh seluruh unit kerja agar setiap unit kerja dapat berpartisipasi secara aktif mendonasi fotofoto kegiatan tridharma perguruan tinggi serta foto-foto kegiatan administrasi pimpinan masing-masing unit kerja. Keberadaan artikel ini, juga merupakan upaya untuk mensosialisasikan sekaligus sebagai hasil dari kegiatan penelitian ini.

\section{PUBLIKASI ARSIP FOTO MELALUI MEDIA WEBSITE SEBAGAI IMPLEMENTASI KEBIJAKAN KETERBUKAAN INFORMASI PUBLIK}

Tachjan (2006: 24) menyarikan dari berbagai pendapat para ahli kebijakan publik tentang pengertian implementasi dan kebijakan publik sebagai berikut, bahwa secara etimologis implementasi mengandung arti sebagai suatu aktivitas yang bertalian dengan penyelesaian suatu pekerjaan dengan penggunaan sarana (alat) untuk memperoleh hasil. Lebih lanjut, apabila pengertian tersebut dirangkaikan dengan kata kebijakan publik, maka rangkaian kata implementasi kebijakan publik dapat diartikan sebagai aktivitas penyelesaian atau pelaksanaan suatu kebijakan publik yang telah ditetapkan/disetujui dengan penggunaan sarana (alat) untuk mencapai tujuan kebijakan.

Kebijakan Keterbukaan Informasi Publik merupakan amanah reformasi yang bergulir di Indonesia pada akhir abad 20. Sejarah tata kelola pemerintahan di era Orde Baru menunjukkan terjadinya tata kelola pemerintahan yang buruk, hingga pada tahun 1997 mengalami krisis ekonomi yang berkepanjangan menjadi krisis politik, ekonomi dan rendahnya kepercayaan rakyat Indonesia pada pemerintah akibat dari praktik korupsi, kolusi dan nepotisme. Bank dunia dan para Negara donor menemukan bahwa bantuan Negara asing yang diberikan kepada Negara-negara berkembang mengalami "kebocoran" sehingga terjadi pemerintahan yang buruk. Indikatornya adalah pemerintahan yang tidak akuntabel, tidak transparan, penyalahgunaan wewenang, korupsi, dan lain-lain (Santoso, 2008;

Kartasasmita,http://www.ginandjar.com/pu blic/01KrisisEkonomidanMasaDepan.pdf;

Yustika, http://download.portalgaruda. org/article.php?article $=67635 \& \mathrm{val}=$ 35267635\&val=352; Center for International Development at Harvard University, http://www.cid.harvard.edu/cidtrade/issues/ Washington.html; Rodrik, D., 
https://www.sss.ias.edu/files/pdfs/Rodrik/R esearch/Goodbye-Washington.pdf).

Bank dunia dan para negara donor memberikan syarat kepada pemerintah negara-negara berkembang, bahwa apabila pemerintah negara berkembang tersebut menginginkan mendapat donor, maka pemerintah tersebut harus menerapkan prinsip tata kelola pemerintahan yang baik (Santosa, 2008). Tata kelola pemerintah yang baik meliputi participatory, consensus oriented, accountable, transparent, responsive, effective and efficient, equitable and inclusive dan follows the rule of law (Yap, K.S., http://www.unescap.org./sites/default/files/ good-governance.pdf; Santosa, 2008).

Kebijakan keterbukaan informasi publik merupakan bagian dari komponen transparent. Pada bagian konsideran huruf b, Undang-Undang Nomor 14 Tahun 2008 tentang Keterbukaan Informasi Publik disebutkan:

"bahwa hak memperoleh informasi merupakan hak asasi manusia dan keterbukaan informasi publik merupakan salah satu ciri penting negara demokratis yang menjunjung tinggi kedaulatan rakyat untuk mewujudkan penyelenggaraan Negara yang baik”.

Selanjutnya, pada bagian konsideran huruf c dari undang-undang yang sama disebutkan:

"bahwa keterbukaan informasi publik merupakan sarana dalam mengoptimalkan pengawasan publik terhadap penyelenggaraan negara dan Badan Publik lainnya dan segala sesuatu yang berakibat pada kepentingan publik”.

Mengacu pada ketentuan tersebut, maka berdasar pada Pasal 7 ayat (2) UndangUndang Nomor 14 Tahun 2008 tentang Keterbukaan Informasi Publik diatur ketentuan, bahwa Badan Publik wajib menyediakan Informasi Publik yang akurat, benar, dan tidak menyesatkan.

Universitas Diponegoro sebagai perguruan tinggi negeri merupakan Badan Publik. Berdasar pada Pasal 1 butir 3 Undang-Undang Nomor 14 Tahun 2008 tentang Keterbukaan Informasi Publik disebutkan:

"Badan Publik adalah lembaga eksekutif, legislative, yudikatif, dan badan lain yang fungsi dan tugas pokoknya berkaitan dengan penyelenggaraan negara, yang sebagian atau seluruh dananya bersumber dari Anggaran Pendapatan dan Belanja Negara dan/atau Anggaran Pendapatan dan Belanja Daerah, atau organisasi non pemerintah sepanjang sebagian atau seluruh dananya bersumber dari Anggaran Pendapatan dan Belanja Negara dan/atau Anggaran Pendapatan dan Belanja Daerah, sumbangan masyarakat, dan/atau luar negeri”.

Dengan demikian diketahui, bahwa Universitas Diponegoro juga memiliki kewajiban untuk memberikan informasi publik kepada pemohon informasi publik. Pemohon informasi publik menurut Pasal 1 butir 12 Undang-Undang Nomor 14 Tahun 2008 tentang Keterbukaan Informasi Publik adalah "warga Negara dan/atau badan hukum Indonesia yang mengajukan permintaan informasi publik sebagaimana diatur dalam Undang-Undang ini”. Meskipun demikian, perguruan tinggisebagai Badan Publik memiliki Hak untuk tidak memenuhi permintaan informasi oleh publik.Hak ini diatur dalam Pasal 6, Pasal 7 ayat (1), (4), (5).Undang-Undang Nomor 14 Tahun 2008 tentang Keterbukaan Informasi Publik). Kelenturan dari UndangUndang Keterbukaan Informasi Publik juga dilihat pada Pasal 8 yang mengatur, bahwa pemberian informasi kepada publik yang berkaitan dengan kearsipan dan pendokumentasian informasi publik berdasarkan pada peraturan perundangundangan. Maka, diseminasi informasi berbasis arsip foto merujuk kepada Undang- 
Undang Nomor 43 tahun 2009 tentang Kearsipan.

Roberts (1993) mengkategorikan arsip foto sebagai arsip bentuk khusus. Robert (1993:387-388; Herdiyanto: 2001) berpendapat, bahwa nilai utama dari sebuah foto adalah pada informasi yang dikandung pada subyek foto. Informasi yang dikandung dalam sebuah foto pada umumnya mengandung nilai yang tinggi.Selain itu fotografer juga mendapat berbagai informasi lebih dari yang diharapkan ketika dia merekam suatu momen. Disisi lain, Roberts (1993) dan Herdiyanto (2001) berpendapat, bahwa tidak semua foto layak untuk disimpan. Oleh sebab itu, dilakukan penilaian terhadap informasi yang dikandung pada setiap arsip, sebelum dilakukan tindakan pengaturan dan pendeskripsian, pemeliharaan dan perawatan, penyimpanan arsip foto. Faktorfaktor yang perlu diperhatikan dalam proses penilaian terhadap nilai informasi yang dikandung di dalam suatu foto adalah: Subjek, Umur, Keunikan, Kualitas, Identifikasi, Kuantitas.Nilai informasi yang terkandung di dalam arsip foto, merupakan alasan mengapa diperlukan biaya untuk pengawasan dan pemeliharaan terhadap arsip foto.

Bowo Herdiyanto seorang penggemar fotografi sekaligus dengan latar belakang pegawai di lingkungan Badan Perpustakaan dan Kearsipan Provinsi Jawa Timur pada tahun 2001 menulis di Bulletin Suara Badar tentang Nilai Informasi Pada Arsip Foto. Sebagai seorang penggemar fotografi dengan latar belakang pekerjaan dibidang kearsipan, tentu Herdiyanto memiliki pengalaman teoritis dan empiris tentang nilai informasi yang terkandung di dalam arsip foto. Herdiyanto di dalam artikel tersebut menuturkan sebagai berikut:

"Hasil fotografi adalah bentuk rekaman penyaksian serta motivasi pengambilan foto akan memberikan beragam nilai informasi. Contoh: a. Foto dapat merekam peristiwa atau kejadian untuk pemberitaan, bahan bukti dan pelengkap pemberitaan. Kumpulan daripadanya yang disusun selektif dan kronologis dapat merupakan penggambaran fakta dan dokumentasi dalam sejarah.

b. Foto tentang sesuatu atau keadaan setempat dapat merupakan apresiasi budaya yang membimbing rasa seni.

c. Foto dapat menerangkan detail suatu benda untuk keperluan studi ilmiah.

d. Foto dapat merekam subyektifitas pandangan sekaligus sebagai usaha eksperimental dalam bidang seni rupa."

Paparan Herdiyanto menunjukkan peran arsip foto sebagai sumber informasi, dan apabila kumpulan gambar dari suatu peristiwa dikelola secara kronologis dapat memberikan gambaran yang utuh dan runtut tentang perjalanan sejarah suatu peristiwa. Meskipun demikian, Herdiyanto menyayangkan, bahwa perkembangan fotografi yang menghasilkan foto dengan kandungan nilai informasi masih minim.

\section{WEBSITE KHAZANAH ARSIP FOTO}

Pada sub 1 telah dijelaskan, bahwa dalam pelaksanaan keterbukaan informasi publik berbasis arsip mengacu pada undangundang kearsipan. Undang-Undang Nomor 43 Tahun 2009 tentang Kearsipan telah mengatur tentang penggunaan arsip dinamis maupun statis bagi pengguna yang berhak untuk mengakses arsip tersebut untuk dimanfaatkan informasinya. Ketentuan tersebut diatur dalam Pasal 1 butir 25 dan 26, Pasal13 huruf c dan d, Pasal 40 ayat (2) huruf b, Pasal 42 ayat (1), Pasal 44, Pasal 46, Pasal 59 ayat (2) huruf d, Pasal 64, 65, 66, 67, 71, 74, 101, 102.

Peraturan Pemerintah Nomor 28 tahun 2012 tentang Pelaksanaan Undang-Undang Nomor 43 Tahun 2009 tentang Kearsipan sesuai dengan ketentuan dalam Pasal 46 Undang-Undang Nomor 43 tahun 2009 
tentang Kearsipan, telah mengatur tentang penciptaan, penggunaan dan pemeliharaan arsip dinamis. Khusus tentang penggunaan arsip dinamis dan statis, maka ketentuannya adalah dimuat dalam Pasal 1 butir 20 dan 21.Selanjutnya diatur dalam Pasal 37, 38, 39, 101, 102, 152.

Seiring dengan dinamika pembangunan nasional yang senantiasa mengikuti perkembangan kemajuan zaman, maka informasi juga dapat diperoleh melalui perangkat teknologi informasi.Terkait dengan ketentuan perundang-undangan kearsipan yang memungkinkan bagi publik untuk mengakses arsip sepanjang tidak bertentangan dengan perundangundangan kearsipan, maka arsip dengan kategori tersebut dapat disajikan dalam bentuk elektronik. Ketentuan tersebut telah diatur dalam Pasal 68 dan 69 UndangUndang Nomor 43 Tahun 2009 tentang Kearsipan, serta Pasal 37 ayat (5) Peraturan Pemerintah Nomor 28 Tahun 2012 tentang Pelaksanaan Undang-Undang Nomor 43 Tahun 2009 tentang Kearsipan.

Universitas Diponegoro sebagai Badan Publik dapat memberikan informasi kepada masyarakat terkait penyelenggaraan pendidikan tinggi oleh universitas tersebut secara elektronik. Khazanah arsip foto sebagai kekayaan informasi Universitas Diponegoro dapat dilayankan kepada publik melalui media elektronik sehingga publik dapat mengakses informasi berupa foto yang mereka butuhkan melalui media tersebut.Hak publik ini dimuat dalam bagian konsideran huruf a Undang-Undang Nomor 25 Tahun 2009 tentang Pelayanan Publik yang menyebutkan, bahwa negara berkewajiban melayani setiap warga negara dan penduduk untuk memenuhi hak dan kebutuhan dasarnya dalam kerangka pelayanan publik yang merupakan amanat Undang-UndangDasar Negara Republik Indonesia Tahun 1945.

Langkah menuju penciptaan website khazanah arsip foto Undip adalah sebagai berikut:

\section{Penyempurnaan Penataan Khazanah Arsip Foto Undip Hasil Alih Media}

Dalam Undang-Undang Nomor 43 Tahun 2009 tentang Kearsipan Pasal 40 ayat (4) diatur tentang empat pilar untuk mendukung pengelolaan arsip dinamis yang efektif dan efisien, yaitu Tata Naskah Dinas, Klasifikasi Arsip, Klasifikasi Keamanan Arsip, Jadwal Retensi Arsip. Tata Naskah Dinas merupakan pintu gerbang sistem kearsipan, Klasifikasi arsip adalah pola pengaturan arsip secara berjenjang dari hasil pelaksanaan fungsi dan tugas instansi menjadi beberapa kategori unit informasi kearsipan. Kode Klasifikasi Arsip adalah simbol atau tanda pengenal suatu struktur fungsi yang digunakan untuk membantu menyusun tata letak identitas arsip. Pedoman Pembuatan Sistem Klasifikasi Keamanan dan Akses Arsip Dinamis adalah suatu pedoman yang diciptakan karena undang-undang keterbukaan informasi publik meng-amanahkan penyediaan informasi bagi publik, namun penyajian informasi berbasis arsip diatur berdasar undang-undang kearsipan. Didalam ketentuan tersebut ditetapkan, bahwa keberadaan Pedoman Pembuatan Sistem Klasifikasi Keamanan dan Akses Arsip Dinamis untuk arsip dinamis. Jadwal Retensi Arsip adalah daftar yang berisi sekurang-kurangnya jangka waktu penyimpanan atau retensi, jenis arsip, dan keterangan yang berisi rekomendasi tentang penetapan suatu jenis arsip dimusnahkan, dinilai kembali, atau dipermanenkan yang dipergunakan sebagai pedoman penyusutan dan penyelamatan arsip. Dalam kegiatan penyempurnaan penataan khazanah arsip foto Undip, hanya diperlukan Klasifikasi Arsip Foto, karena penting untuk mengorganisir khazanah arsip foto yang sudah terseleksi, juga sebagai pedoman dalam penataan fisik foto berikut deskripsinya, serta foto hasil alih media berikut deskripsinya. 
Berdasar pada temuan terhadap hasil penelitian sebelumnya, maka dilakukan Focus Group Discussion antara tim peneliti, pengelola Program Studi Diploma III Kearsipan, Pengelola Laboratorium Arsip Media Baru Program Studi D III Kearsipan dan developer website Khazanah Arsip Foto Undip. Grup menyimpulkan, bahwa perlu dilakukan penyempurnaan penataan khazanah arsip foto Undip hasil alih media/digital. Tujuan penyempurnaan adalah untuk me-maksimalkan maksud dari penelitian ini, yaitu untuk memudahkan akses terhadap informasi tentang penyelenggaraan pendidikan tinggi di Universitas Diponegoro secara efektif dan efisien. Informasi yang dimaksud berupa foto hasil dokumentasi kegiatan tridharma perguruan tinggi dan administrasi pimpinan Universitas Diponegoro. Setelah dilakukan evaluasi, maka diketahui bahwa sistem penataan dengan menggunakan pola kronologis penciptaan foto sebagai subyek utama, diikuti dengan tema kegiatan sebagai sub subyek belum mampu menghasilkan temu balik yang efektif dan efisien. Hasil pengujian internal diketahui, bahwa pengguna potensial informasi penyelenggaraan pendidikan tinggi di Universitas Diponegoro cenderung mengajukan pertanyaan pada periode kepemimpinan, kemudian diikuti dengan tema kegiatan sebagai sub subyek, dan kronologis kegiatan sebagai sub sub subyek. Maka, disusun klasifikasi arsip foto sebagaimana dalam Lampiran 1.

Bagan 1.Struktur temu balik informasi dengan pola berikut.

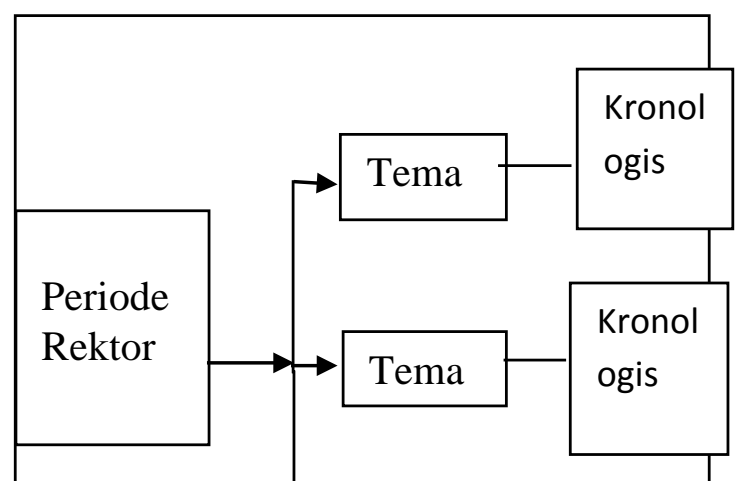

\section{Pembuatan Desain Website}

Ketika seseorang atau suatu organisasi akan membuat website, maka dilakukan persiapan pembuatan website. Dalam proses persiapan pembuatan website maka perlu dilakukan pembuatan desain website. Dalam pembuatan desain website foto, maka perlu dipetakan terlebih dahulu siapakah pengguna potensial website ini. Karena keberadaan website ini diharapkan sebagai tindak lanjut atas amanah Undang-Undang Nomor 43 Tahun 2009 tentang Kearsipan, maka pengguna potensial website ini bukan hanya dari kalangan internal Universitas Diponegoro dan alumni saja, tetapi juga masyarakat umum, sebagai memori kolektif dan sumber ilmu pengetahuan bagi para penggunanya.

Hasil kajian pustaka terkait pembuatan website dan hasil konsultasi tim peneliti dengan Arsiparis pengelola arsip foto dan pengelola IT Badan Arsip dan Perpustakaan Provinsi Jawa Tengah dibahas oleh tim peneliti, pengelola Program Studi D III Kearsipan, dan pengelola laboratorium Arsip Media Baru serta developer terpilih dalam bentuk workshop dengan agenda khusus pembahasan fitur yang akan ditampilkan beserta lay out website. Hasil yang dicapai adalah fitur terdiri dari: Home, Pencipta Arsip, Index, Buku Tamu, Jumlah pengunjung harian/mingguan/bulanan, Cari Arsip, Buku Pinjam, Deskripsi foto. Terkait dengan pembuatan desain website, maka deskripsi harus sudah disiapkan karena worksheet memuat deskripsi foto. Simpulan tim peneliti dalam workshop internal tentang desain website khazanah arsip foto yang 
ideal adalah ketika suatu item foto tampil, maka pada layar dapat sekaligus diketahui deskripsi dari foto tersebut. Kami menyebut pemikiran ini sebagai konsep all in one. Pemikiran ini muncul, karena sistem kearsipan yang efektif dan efisien ditunjukkan dengan kemudahan para pengguna untuk mengakses informasi. Worksheet dalam konteks ini berfungsi sebagai sarana bantu temu balik elektronik terhadap foto yang dikehendaki pengguna lengkap dengan deskripsinya.

Desain website arsip foto dengan konsep all in one harus sudah siap sebelum berkas arsip foto di upload. Mengingat bahwa pelayanan informasi berbasis arsip foto akan di upload ke internet, maka worksheet juga harus berbasis web. Dengan pertimbangan tersebut, maka Worksheet deskripsi arsip foto dibuat dengan memanfaatkan program Microsoft Excel. Fungsi worksheet ini adalah sebagai sarana bantu temu balik arsip foto yang dicari oleh pengguna. Dengan dukungan web base, maka secara keseluruhan informasi meliputi deskripsi maupun visual foto dapat disajikan dalam satu layar. Deskripsi arsip foto memuat informasi mengenai objek apa yang ada di dalam foto? siapa? dimana? kapan? mengapa? bagaimana? Sebagai gambaran dari worksheet tersebut dapat dilihat pada Lampiran 2.

Worksheet ini bila telah di-upload ke website khazanah arsip foto Universitas Diponegoro, dapat berfungsi sebagai sarana bantu temu balilk arsip foto seperti yang diinginkan oleh penggunanya. Para calon pengguna website ini juga dapat mengetahui apakah foto yang mereka cari dikelola oleh Laboratorium D III Kearsipan FIB Undip atau tidak. Semua proses itu dapat diketahui oleh pengguna dengan cepat dan mudah.

Manual aplikasi arsip foto berbasis web disiapkan oleh developer untuk panduan bagi administrator untuk menambah dan mengedit file yang diinput. Bahasa pemrograman yang digunakan adalah PHP (Hypertext Pre-processor). PHP merupakan bahasa pemrograman yang paling banyak digunakan di Indonesia (Ardhana, 2014: 65). Bahkan Wikipedia melansir bahwa kemudahan dan kepopuleran PHP sudah menjadi standar bagi programmer web di seluruh dunia. Pada Februari 2014 terdapat sekitar $82 \%$ dari web server di dunia menggunakan PHP. Keunggulan bahasa pemrograman PHP adalah (Ardhana, 2014: 65):

1. PHP memiliki native API untuk koneksi ke berbagai database sehingga secara otomatis dalam melakukan koneksi lebih cepat dibandingkan dengan Open Database Conectivity (ODBC).

2. Eksekusi scripting dilakukan lebih cepat sehingga meningkatkan throughout pada server.

3. Penulisan program yang simple dan sederhana yang membuat programmer newbie (pemula) mudah dalam memahami PHP.

4. Dukungan koneksi yang hampir bisa dilakukan ke semua database seperti MySQL, PostgreSQL, Sybase, Infomix, Interbase, ORACLE, SQL server, dan lain-lain.

5. PHP dapat dijalankan di beberapa web server seperti PWS, IIS, Apache, Xitami, Netscape Enterprise, AOL server dan Orelly website pro, CGI dan ISAPI.

6. PHP juga dapat berjalan di berbagai platform seperti Unix dan Windows.

7. PHP dapat didistribusikan kembali dibawah lisensi Gnu Public License (GPL) karena bersifat open source.

\section{Menyiapkan Domain (alamat akses dari web)}

Domain adalah sebuah nama yang unik yang berfungsi untuk mengidentifikasi alamat IP. Dengan menggunakan Domain seseorang tidak perlu menghapal serangkaian IP Address sehingga memudahkan dalam menghapal maupun pengucapan. IP Address adalah sebuah alamat pada komputer agar komputer bisa saling terhubung dengan komputer lain, IP 
Address terdiri dari 4 Blok, setiap Blok di isi oleh angka 0 - 255. Contoh IP Address seperti 192.168.100.1, 10.57.38.223, ini adalah IPv4.

Berikut adalah nama nama domain beserta fungsinya:

gov- Digunakan Untuk Pemerintahan edu-Digunakan Untuk Institusi pendidikan org - Digunakan Untuk Organisasi / Kegiatan Nonprofit

mil - Digunakan Untuk Militer

com - Digunakan Untuk Organisasi Profit / Komersial

net - Digunakan Untuk Organisasi Network name - Digunakan untuk personal / keluarga tv - Digunakan Untuk Pertelevisian info - Digunakan Untuk kepentingan Informasi

biz - Digunakan Untuk Kepentingan Bisnis travel - Digunakan Untuk Pariwisata

xxx - Digunakan untuk Hiburan Dewasa (Pornografi)

dan masih banyak lagi

Tim peneliti telah melakukan konsultasi dengan berbagai pihak terkait untuk meminta izin tentang domain website khazanah arsip foto Undip.Konsultasi dilakukan kepada Kepala BAUK Undip, Kepala UPT Pusat Komputer Undip dan Dekan Fakultas Ilmu Budaya.Hasilnya, website khazanah arsip foto Undip menggunakan domain yang dimiliki Undip, yaitu undip.ac.id.

\section{1) Menyiapkan hosting}

Hosting adalah "rumah" untuk mempublikasikan informasi, yang kita menginginkan publik untuk membacanya. Pada tahap "hosting" ini, yang perlu dipikirkan adalah:

a. Kebutuhan terhadap space dan bandwidth. Semakin banyak tulisan yang akan kita muat, maka semakin besar space yang akan dibutuhkan. Semakin banyak pengunjung website, maka semakin besar bandwidth yang dibutuhkan. Tujuannya adalah agar tidak terjadi server full load.

b. Perhatikan layanan dan fitur dari tempat kita akan meng-hosting-kan website kita. Bisa mencakup software apa saja yang ada dihosting-nya.

c. Target pembaca. Jika target pembaca website kita adalah pembaca dari dalam negeri, maka sebaiknya menggunakan server lokal agar lebih menghemat bandwidth. Tetapi jika kita memilih target yang global, maka kita memilih server luar negeri seperti di Amerika.

Hasil konsultasi dengan Kepala UPT Pusat Komputer Universitas Diponegoro pada hari Rabu, 19 Agustus 2015 diperoleh penjelasan, bahwa permasalahan space dan bandwidth dapat diatasi bila penyelenggara menyediakan server sendiri untuk keperluan pelayanan informasi kepada publik tentang penyelenggaraan tridharma perguruan tinggi Universitas Diponegoro dan administrasi pimpinan Universitas Diponegoro. Dengan demikian, pengelola arsip universitas Diponegoro nantinya dapat leluasa mengupload informasi berbasis arsip untuk keperluan pelayanan informasi kepada publik.

\section{2) Pembuatan Program Temu Balik Arsip Foto Berbasis Web}

Fokus kegiatan penelitian ini adalah tentang Digitalisasi Arsip Foto Universitas Diponegoro Sebagai Landasan Implementasi Kebijakan Keterbukaan Informasi Publik. Wujud nyata keterbukaan informasi publik mempublikasi-kan kegiatan tridharma perguruan tinggi di lingkungan Universitas Diponegoro, serta kegiatan administrasi pimpinan 
Universitas Diponegoro melalui website. Media arsip yang dipublikasikan adalah arsip foto. Setelah desain website selesai dibangun, maka langkah pembuatan program temu balik arsip foto berbasis web adalah sebagai berikut:

a. Halaman Login

Langkah awal dalam pembuatan program temu balik arsip foto berbasis web adalah melakukan login dengan masukkan username dan password dengan benar. Setelah itu, klik Login

b. Halaman Administrator

Halaman administrator akan muncul setelah kita melakukan Login. Halaman ini berisikan semua menu yang bisa diakses oleh user untuk mendapatkan informasiinformasi yang dibutuhkan pada Aplikasi Arsip FotoBerbasis Web pada Arsip Universitas Diponegoro

c. Pencipta Arsip

Hal utama yang harus dilakukan adalah mendaftar-kan semua pencipta arsip yang ada di Universitas Diponegoro Semarang. Klik menu PENCIPTA ARSIP, maka akan tampil halaman PENCIPTA ARSIP. Halaman ini memuat daftar pencipta arsip yang sudah didaftarkan di dalam aplikasi.

d. Untuk menambah Pencipta Arsip, klik tombol Tambah Data yang terdapat di kanan bawah tabel. Klik tombol Add New Data untuk menyimpan data.

e. Sedangkan untuk edit nama pencipta arsip, klik nama Pencipta Arsip dalam tabel.

Klik tombol Update Data untuk menyimpan data.

f. Terdapat kolom Action dengan icon $\mathbf{R}$ yang berarti Riwayat Akuisisi.
Klik icon tersebut maka akan tampil Riwayat Akuisisi dari Pencipta Arsip yang dipilih.

Hasil dari pembuatan program ini telah di-upload secara offline. Dengan diunggahnya informasi kegiatan tridharma perguruan tinggi Universitas Diponegoro dan administrasi pimpinan Universitas Diponegoro melalui website resmi Universitas Diponegoro, maka website ini menjadi landasan bagi perguruan tinggi ini dalam meng-implementasi Kebijakan Keterbukaan Informasi Publik.

\section{SIMPULAN}

Simpulan penelitian ini,bahwa hasil dari focus group discussion perlu dilakukan penyempurnaan terhadap klasifikasi arsip foto yang telah disusun pada penelitian sebelumnya.Penyempurnaan perlu dilakukan karena draft yang telah disusun pada penelitian sebelumnya tidak maksimal digunakan untuk proses temu kembali arsip foto. Penataan yang semula menggunakan sistem kronologis, yaitu kronologis penciptaan foto sebagai subyek utama, diikuti tema kegiatan sebagai sub-subyek dinilai sulit untuk digunakan sebagai sistem temu balik yang efektif dan efisien. Klasifikasi hasil penyempurnaan adalah Periode Kepemimpinanan Perguruan Tinggi sebagai subyek utama, diikuti dengan tema pada sub-subyek dan kronologis kegiatan sebagai sub sub-subyek.

Desain website khazanah arsip foto Undip yang ideal memuat fitur Home, Pencipta Arsip, Index, Buku Tamu, Jumlah pengunjung harian/ mingguan/ bulanan, Cari Arsip, Buku Pinjam, Deskripsi foto. Seluruh fitur yang disiapkan terkait dengan arsip dengan media foto saja. Tujuannya adalah untuk memudahkan temu kembali foto yang diperlukan oleh pengguna.

Hubungan antara digitalisasi arsip foto Universitas Diponegoro dengan implementasi kebijakan keterbukaan 
informasi publik adalah arsip digital merupakan media arsip yang disyaratkan untuk dapat di-upload ke website. Arsip foto digital yang dilengkapi dengan deskripsi arsip foto elektronik merupakan komponen all in one sehingga informasi tentang suatu foto tentang kegiatan tridharma perguruan tinggi maupun foto kegiatan administrasi pimpinan perguruan tinggi dapat disajikan kepada publik sebagai sumber informasi melalui program website. Program ini dapat diakses oleh para penggunanya secara online.

\section{DAFTAR PUSTAKA}

\section{Buku}

Ardhana, YM Kusuma. 2014. Project PHP \& MySQL Membuat Website Buku Digital. admin@jasakom.com

Roberts, David. 1993. "Managing Records in Special Formats di dalam Ellis", Judith. Keeping Archives (Second Edition). Port Melbourne: The Australian Society of Archivists Inc.
Sugiarto, Agus dan Teguh Wahyono, 2005, Manajemen Kearsipan Modern, Yogyakarta: Gava Media

Tachjan, 2006, Implementasi Kebijakan Publik. Bandung: Asosiasi Ilmu Politik Indonesia (AIPI) Bandung bekerjasama dengan Puslit KP2W Lembaga Penelitian Unpad.

\section{Perundang-undangan yang berlaku secara umum}

Undang-Undang Nomor 11 Tahun 2008 tentang Informasi dan Transaksi Elektronik.

Undang-Undang Nomor 14 Tahun 2008 tentang Keterbukaan Informasi Publik

Undang-Undang Nomor 25 Tahun 2009 tentang Pelayanan Publik.

Undang-Undang RI Nomor 43 Tahun 2009 tentang Kearsipan.

Undang-Undang Republik Indonesia Nomor 12 Tahun 2012 tentang Pendidikan Tinggi.

Peraturan Pemerintah Nomor 61 Tahun 2010 tentang Pelaksanaan Undang-undang Nomor 14 Tahun 2008 tentang Keterbukaan Informasi Publik.

Peraturan Kepala Arsip Nasional Republik Indonesia Nomor 17 Tahun 2011 tentang Pedoman Pembuatan Sistem
Klasifikasi Keamanan dan Akses Arsip Dinamis.

Peraturan Kepala Arsip Nasional Republik Indonesia Nomor 20 Tahun 2011 tentang Pedoman Autentikasi Arsip Elektronik.

Peraturan Bersama Kepala Arsip Nasional Republik Indonesia dan Kepala Badan Kepegawaian Negara Nomor 08 Tahun 2012 dan Nomor 15 Tahun 2012 tentang Pedoman Retensi Arsip Kepegawaian Pegawai Negeri Sipil dan Pejabat Negara.

Peraturan Kepala Arsip Nasional Republik Indonesia Nomor 19 Tahun 2012 tentang Pedoman Penyusunan Klasifikasi Arsip.

Peraturan Kepala Arsip Nasional Republik Indonesia Nomor 6 Tahun 2013 
HUMANIKA Vol. 22 No. 2 (2015) ISSN 1412-9418

Digitalisasi Arsip Foto Universitas Diponegoro sebagai Landasan Implementasi

Kebijakan Keterbukaan Informasi Publik

Tri Handayani, Amin Taufiq Kurniawan

tentang Pedoman Retensi Arsip

Keuangan.
Peraturan Kepala Arsip Nasional Republik Indonesia Nomor 2 Tahun 2014 tentang Pedoman Tata Naskah Dinas.

\section{Bulletin}

Bowo Herdiyanto, Nilai Informasi Pada Arsip Foto, Bulletin Suara Badar 2/2001, Badan Perpustakaan dan Kearsipan Provinsi Jawa Timur.

\section{Wesite}

Ahmad Prayitno, http://ahmadprayitno.com/2011/09/pengertiandomain/. Diunduh 8 Agustus 2015

Andre,

http://www.duniailkom.com/pengerti an-dan-fungsi-php-dalam-

pemograman-web/.

Diunduh Minggu 9 Agustus 2015

Center for International Development at Harvard University,

http://www.cid.harvard.edu/cidtde/is sues/Washington.html; Diunduh 17 Mei 2015

Christian, http://www.adalahcara. com/2013/05/pengertian-kelas-ipaddress-adalah.html.

Diunduh 8 Agustus 2015

Muhammad Zainuri, http://berita. suaramerdeka.com/smcetak/gerbangmenuju-universitas-riset/. Diunduh 12 Agustus 2015

Rodrik, D., https://www.sss.ias.edu/files/pdfs/Ro drik/Research/GoodbyeWashington.pdf.Diunduh 17 Mei 2015

Rohimahyati, https://rohimahyati.wordpress.com/2 010/05/21/pengertian-hosting/

Diunduh 8 Agustus 2015

Yustika, http://download.portalgaruda.org/arti cle. php?article $=67635 \& \mathrm{val}=35267635 \& \mathrm{val}=352 \mathrm{Di}$ unduh17 Mei 2015

Kartasasmita,

http://www.ginandjar.com/public/01Krisis

EkonomidanMasaDepan.pdf.

Diunduh 13 Mei 2015 
HUMANIKA Vol. 22 No. 2 (2015) ISSN 1412-9418

Digitalisasi Arsip Foto Universitas Diponegoro sebagai Landasan Implementasi

Kebijakan Keterbukaan Informasi Publik Tri Handayani, Amin Taufiq Kurniawan

Lampiran 1. Klasifikasi Arsip Foto

\section{Rancangan Klasifikasi Arsip Foto} Universitas Diponegoro

A. TRI DHARMA PerguruanTinggi

1. Pendidikan

1.1. PenerimaanMahasiswa Baru

1.2. Testing Mahasiswa Baru

1.3. Wisuda

2. Penelitian

2.1 PenelitianDosen

2.2 PenelitianMahasiswa

3. PengabdianKepadaMasyarakat

3.1. $\mathrm{KKN}$

3.2. Penyuluhan

3.3. KORPRI

3.4 DharmaWanita

3.5 Koperasi

3.6 BantuanSosial

3.7 Pameran/Bazar
B. Kepegawaian dan Pengembangan SDM

1. Penerimaan CPNS

2. Testing CPNS

3. Penataran P4

4. Diklat Pegawai

5. Workshop Pegawai

C. UPACARA

1. Upacara 17 Agustus

2. Upacara Korpri dan HariHariNasional

3. Upacara Pemberangkatan $\mathrm{KKN}$

4. Upacara Wisuda

5. Upacara Dies Natalis

6. Upacara Pengukuhan Guru Besar

7. Upacara PemberangkatanJenazah Guru Besar

D. Kerjasama

1. Tamu Luar Negeri

2. Tamu DalamNegeri

3. Tamu Pejabat

4. Penandatanganan MOU

E. Olahraga/Pentas Seni

Lampiran 2. Visualisasi Worksheet Deskripsi Arsip Foto

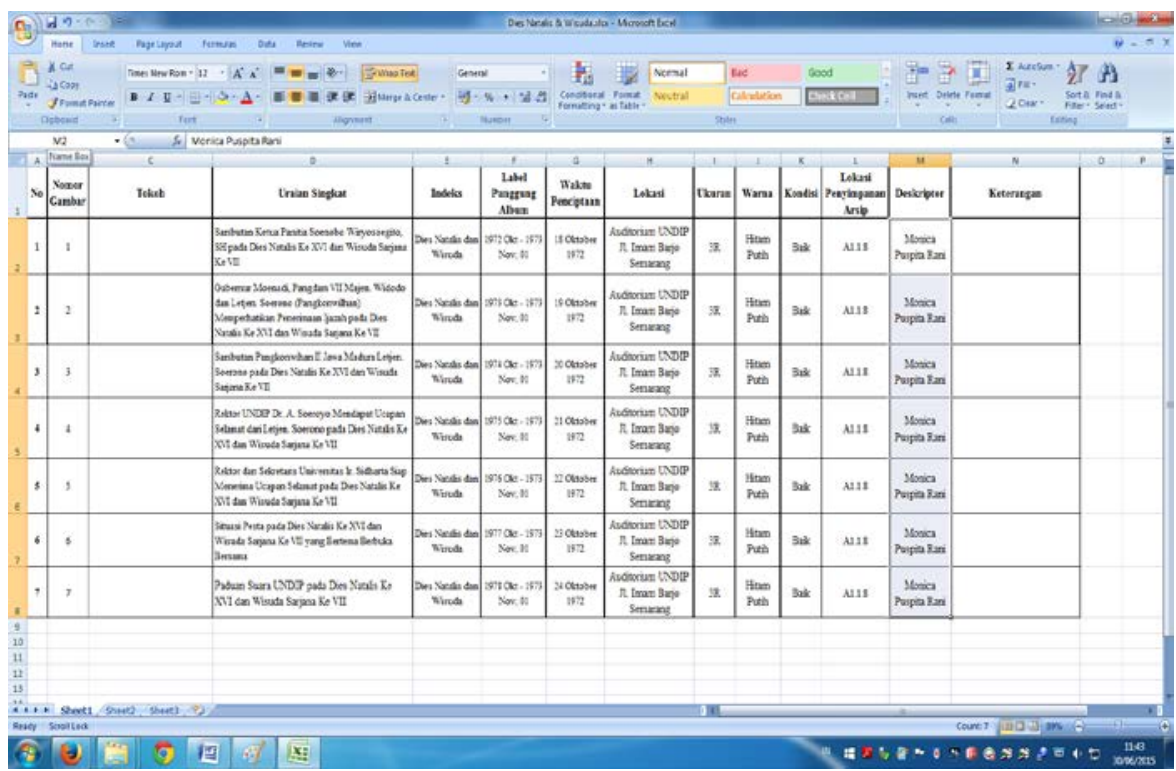

